\title{
Mid-level bureaucrats perception on the implementation of public policies
}

\author{
Valéria de Oliveira Lemos Novato 1 \\ Estela Najberg 1 \\ Gabriela Spanghero Lotta ${ }^{2}$
}

1 Universidade Federal de Goiás / Faculty of Administration, Accounting and Economic Sciences, Graduate Program in Adminis-

tration, Goiânia / GO - Brazil

2 Fundação Getulio Vargas (FGV EAESP) / Graduate Program in Public Administration and Government, São Paulo / SP - Brazil

This article contributes to studies about the perceptions of mid-level bureaucrats on the implementation of public policies. The article empirically analyzes the perceptions of mid-level bureaucrats (MLB) on the implementation of REUNI within the Federal University of Goiás (UFG). A case study was conducted, with documentary research and interviews with MLB. The results demonstrate the importance of institutional support and technical and emotional preparation for MLB to perform appropriately. In empirical terms, the study demonstrates that UFG failed to meet the program's global goals, but has met most of the guidelines set forth by the Ministry of Education, with emphasis on expanding student inclusion and assistance policies, transforming a university that served the elite into an inclusive institution. Unanimously, all MLBs recognize the great importance of REUNI for the UFG in structural and educational terms and that their activities could have been better performed with adequate support and preparation.

Keywords: mid-level bureaucrats; public educational policies; REUNI; policy implementation.

\section{O Burocrata de Médio Escalão na implementação de políticas públicas}

Este artigo busca contribuir com os estudos sobre as percepções de Burocratas de Médio Escalão (BMEs) na implementação de uma política pública. Para tanto, analisam-se empiricamente as percepções dos BMEs na implementação do Programa de Apoio a Planos de Reestruturação e Expansão das Universidades Federais (Reuni) no âmbito da Universidade Federal de Goiás (UFG). Realizou-se um estudo de caso, mediante pesquisa documental e entrevistas com esses burocratas. Os resultados demonstram a importância de que o BME tenha apoio institucional e preparação técnica e emocional para realizar um bom trabalho. Em termos empíricos, demonstra-se que a UFG não conseguiu atender às metas globais do Reuni, porém, cumpriu a maioria das diretrizes estipuladas pelo Ministério da Educação (MEC) em decreto, com destaque para a ampliação de políticas de inclusão e assistência estudantil, transformando uma universidade "elitizada" em uma universidade "igualitária". De modo unânime, os BMEs reconhecem a grande importância do Reuni na UFG, em termos estruturais e de ensino, e que sua atuação poderia ter sido mais bem desempenhada com suporte e preparação adequados.

Palavras-chave: burocracia de médio escalão; políticas públicas educacionais; reuni; implementação de políticas públicas.

\section{El burócrata de nivel medio en la implementación de políticas públicas}

Este artículo se propone contribuir a los estudios sobre las percepciones de los burócratas de nivel medio (BME) en la implementación de políticas públicas. Para ello, se analizan empíricamente las percepciones de los BME en la implementación del Programa de Apoyo a Planes de Reestructuración y Expansión de las Universidades Federales (REUNI) en el ámbito de la Universidad Federal de Goiás (UFG). Se realizó un estudio de caso, con investigación documental y entrevistas con estos burócratas. Los resultados demuestran la importancia de que los BME tengan apoyo institucional, preparación técnica y emocional para hacer un buen trabajo. En términos empíricos, se demuestra que la UFG no logró cumplir los objetivos globales del REUNI, no obstante, cumplió con la mayoría de las directrices estipuladas por el Ministerio de Educación, con énfasis en expandir las políticas de inclusión y asistencia estudiantil, transformando una universidad de "elite" en una universidad "igualitaria". Por unanimidad, los BME reconocen la gran importancia del REUNI en la UFG en términos estructurales y educativos y que su desempeño podría haber sido mejor con el apoyo y la preparación adecuados.

Palabras clave: burocracia de nivel medio; políticas públicas educativas; reuni; implementación de políticas públicas. 


\section{INTRODUCTION}

In recent years, the literature of public policy has been dedicated more and more to understanding how bureaucratic actors influence decision-making processes (Pires, Lotta, \& Oliveira, 2018). In this theoretical effort, various studies have sought to understand which actors matter, the manner in which they have influence, the results of their actions, and their perceptions of public policy, especially in the implementation process (Cavalcante \& Lotta, 2015; Howlett, 2011; Huising \& Silbey, 2011).

Even though these efforts have gained substantial space domestically and internationally (Cavalcante \& Lotta, 2015), a considerable portion of them is still focused on those actors who occupy high level positions (high-level bureaucrats) or those who interact directly with the public which benefits from these policies (street-level bureaucrats). Studies focused on understanding the role and actions of actors who occupy intermediate positions, mid-level bureaucrats (MLBs), are still scarce in the literature (Cavalcante \& Lotta, 2015; Howlett, 2011; V. E. Oliveira \& Abrucio, 2011; Pires, 2011). This article seeks to contribute to this overall effort to understand the actions of bureaucratic actors in decision-making processes of public policy, but with a specific focus on the perceptions of mid-level actors concerning their actions and relevance. Therefore, to fill this gap in studies of policy implementation it seeks to understand how MLBs perceive the policies for which they are responsible and contribute to their implementation.

To accomplish this, this study analyzes the implementation process of the Support Program for Restructuring and Expansion Plans of the Federal Universities (Reuni) in the Federal University of Goiás (UFG), with a focus on the perceptions of the MLBs who acted in this process. MLBs are actors who occupy intermediate positions in the implementation of policies, who are responsible for the management of teams and for the interface between high-level and street-level bureaucrats (Pires et al., 2018). For the purposes of this study of UFG, the MLBs consist of directors of academic units, department heads and paid managers. These are the actors who occupy the intermediate positions between high-level bureaucrats (deans and assistant deans) and street-level bureaucrats (professors and administrative personnel who interact directly with the community or organize the operation of supplied services). The analysis of mid-level bureaucrats of a university constitutes a new object in the national literature, given that a good portion of previous studies have analyzed bureaucrats in the federal government (Cavalcante \& Lotta, 2015), in municipal governments (Andrade, 2018) and social policies implemented directly with the public, such as health and education in schools and health equipment (V. E. Oliveira \& Abrucio, 2011; V. E. Oliveira, Lotta, \& Nunes, 2019).

At the same time, looking at MLBs also contributes to studies of education. Reuni is considered to be very successful in its global results, but with amplitudes and implementations that are complex and vary. Studies of this policy are focused in evaluating its results (Cabral, Romero, Penha, Alves, \& Parente, 2014; A. J. Oliveira, Almeida, Carneiro, \& Scarpin, 2014), with few concerned about analyzing the implementation process, above all in terms of the role of the implementors. An analysis of the implementation process is relevant to understanding the challenges and solutions found in the materialization of a policy (Lotta, 2019) and enables the researcher to develop examples and models to suggest for future implementations. In addition, the choice of an already implemented policy (which makes an ex post policy possible) provides the rich characteristics of analyzing it through the perception of the bureaucrats themselves and how they interpret the actions that they perform. 
Finally, the implementation of this policy in the UFG is especially interesting for studies due to the results achieved by this institution. Considered by Siqueira (2015) to be one of the 10 most efficient institutions that adheres to Reuni, UFG offers a great opportunity to observe the actions of MLBs in terms of this program, extracting examples of management and great contributions to the literature.

Identifying who these MLBs are and what they do in public institutions is already a contribution to overcome the apparent conceptual limbo of this subject, and it is even more relevant to study it from the perspective of an already implemented public policy. Given the relevance of the addressed subject and the gaps identified in the literature, this study seeks to analyze the implementation process of Reuni, from 2007 to 2012, within the context of UFG, based on the perceptions of the MLBs themselves.

This analyzes, therefore, how these actors perceive and interpret the policy implementation process. Based on these perceptions, we will focus on 4 dimensions pointed out by the literature as relevant to understanding the actions of MLBs in policy implementation: a) how structural factors (physical structure, human and financial resources) were planned and executed by MLBs in UFG; b) the behavior of MLBs as managers of the Reuni implementation process; c) the perception of MLBs in terms of the public policy factor (regulation, formulation and planning); and d) the relationship between MLBs and the State, in terms of the autonomy conceded in policy implementation.

\section{DATA AND METHODOLOGY}

As a research strategy, we have adopted the case study as an inductive qualitative approach with a descriptive objective, to seek to understand the policy implementation process, describing and explaining its actions to arrive at our results. The decision to study an implemented policy based on a case study was born from our desire to understand complex social phenomena in greater depth. Case studies allow an investigation to preserve wholistic and significant characteristics of events in real life. In addition, the study's principal tendency is to clarify a decision or a group of decisions: a) the reason why they were made; b) how they were implemented; and c) what were the results (Creswell, 2007; Yin, 2005).

To accomplish this, we selected as our object of analysis the implementation of the Reuni program in UFG, this being an opportunity to study an ex post policy. Reuni was created in 2007 through Decree no. 6,096 (2007), as a result of debates about the government's agenda which had been going on since 2001 in terms of talking about the need to expand Higher Learning in Brazil within the context of the creation of a National Plan of Education (PNE). The Ministry of Education (MEC) fulfilled the role attributed by the PNE when it established the goal of offering Higher Education to at least $30 \%$ of the youths from ages 18 to 24 by the end of the century's first decade (Ministério da Educação [MEC], 2017).

UFG was strategically selected as a research location since it united the necessary elements for obtaining the desired results, and also made analysis viable. With Reuni, UFG practically doubled its number of spaces in the past ten years, turning it into an institution with great potential for the expansion of Higher Learning (Casari, 2014; T. S. Souza, 2017).

The study was conducted based on 3 strategies: a) bibliographic research and an analysis of the literature; b) documental analysis; and c) interviews with MLBs involved in the implementation of the policy. The bibliographic research was performed based on a systematic review of the literature 
(SRL) and the procedures are specific to the presentation of the theoretical portion. The documental analysis examined documents, reports and norms relative to the implementation of Reuni at UFG. It also consulted the university's website. This procedure made it possible to research the actors involved in the policy implementation process, which served as the basis for the selection of the interviewees.

In relation to the interviews, their selection was based on previous research which made it possible to map the main bureaucratic implementers of the Reuni expansion policy at UFG. The MLBs were identified in this institution as those responsible for the management of the implementation of the public policy and they were divided into 2 groups: a) the implementation commission, composed of department heads, professors and paid managers, selected in meetings and invited to participate in the commission; and b) the directors of academic units, responsible for the planning and execution in their respective units. At the time of the field research, we identified 155 organized courses in 43 academic units within UFG. To delimit the interviews, we opted to interview the director of each knowledge area group, following the Coordinating Body for the Improvement of Higher Level Personnel (Capes) classification of 2017: a) Exact and Earth Sciences; b) Biological Sciences; c) Engineering; d) Health Sciences; e) Agricultural Sciences; f) Applied Social Sciences; g) Humanities; and h) Linguistics, Letters and the Arts. This choice was justified by the structure of Reuni itself, which contemplates various areas of knowledge.

This study began with an initial estimate of 17 interviewees from the members of the implementation commission (9 members) and the directors of academic units (8 directors, representing each area of knowledge). However, of the 9 commission members, only 6 made themselves available for an interview. Thus, we had a total of 14 interviewees, with 8 being directors of academic units and 6 members of the Reuni implementation commission at UFG. When they were interviewed, the interviewees signed a free and transparent permission agreement (TCLE), approved by the Ethics Committee of UFG, and agreed to be recorded. Most of the interviewees requested confidentiality, including in the area of knowledge where they act. Given this, we opted to codify the interviewees to preserve their anonymity.

Box 1 presents the descriptions of the interviewees and their respective codification.

BOX 1

FUNCTION, DESCRIPTION, QUANTITY AND CODIFICATION OF THE INTERVIEWEES

\begin{tabular}{|c|c|c|c|}
\hline Function & Description & $\begin{array}{c}\text { Number of } \\
\text { interviewees }\end{array}$ & Codification \\
\hline $\begin{array}{l}\text { Members of the } \\
\text { implementation } \\
\text { commission }\end{array}$ & $\begin{array}{l}\text { Department heads, professors and paid managers, } \\
\text { who composed the commission for the Reuni adhesion } \\
\text { plan at UFG, designated by Decree no. 1,461 of July } \\
13,2007 \text {. }\end{array}$ & 6 & C1 ... C6 \\
\hline $\begin{array}{l}\text { Directors of } \\
\text { academic units }\end{array}$ & $\begin{array}{l}\text { Directors of some academic units which adhered to } \\
\text { the Reuni plan and made themselves available for an } \\
\text { interview. }\end{array}$ & 8 & AU1... AU8 \\
\hline
\end{tabular}

Source: Elaborated by the authors. 
The interviews totaled 6 hours and 12 minutes of audio - all transcribed. The content analysis followed a procedure oriented by the studies of Bardin (2004) in categorizing the results and discussions. We used the Logus Academy software to help perform this analysis, which made it possible to unite the bibliographic and documental research and the audios of the interviews into a single web platform.

The data analysis was organized using 4 predetermined factors (themes) based on SRL which will be presented later on: a) structural factors: physical, human and financial environment; b) the human factor: policy implementors; c) public policy factor: regulations, planning and formulation; and d) the State factor: policy discontinuity, federation and autonomy. These factors guided the construction of a semi-structured script and the analysis categories for this study's results.

\section{MID-LEVEL BUREAUCRACY IN THE IMPLEMENTATION OF PUBLIC POLICY}

During the past few decades, the public policy literature has advanced in the understanding of the actions of bureaucrats in decision-making processes, especially in the policy implementation process (Pires et al., 2018). In an effort to understand the State from within, studies have sought to observe how different bureaucratic strata interact and influence decisions in various phases of the public policy cycle. Studies of the role of high-level bureaucrats have made up a large part of this effort (Codato \& Franz, 2018; Loureiro \& Abrucio, 2018) as well as studies of street-level bureaucrats who interact with users in the delivery of services (Brodkin, 2012; Cavalcante \& Lotta, 2015; Lipsky, 1980).

More recently, part of the literature has been dedicated to analyzing the actors who intermediate between HLBs and SLBs. These actors are termed MLBs in the literature (Howlett, 2011; Pires, 2011; V. E. Oliveira \& Abrucio, 2011). This bureaucracy has been less studied historically, and therefore the way in which it acts and interferes with public policy remains relatively unclear (Cavalcante \& Lotta, 2015). In terms of their relevance, the fact that they are in the middle of organizational structures places MLBs in a "theoretical limbo", with few studies capable of conceptualizing them or understanding their profiles, actions, and importance in public policy (Cavalcante \& Lotta, 2015). At the same time, their great diversity in terms of places, positions and functions also makes the advance of more systematic studies more difficult (Cavalcante, Lotta, \& Yamada, 2018).

The literature has been dedicated to understanding how these actors have demonstrated that they are indispensable to the implementation of policy, to the extent that they act to place them in practice and have the primordial function of translating decisions into actions (Andrade, 2018; Pires et al., 2018). This literature has sought to reveal who these bureaucrats are and what they do so that policy implementation takes place, as well as understand their values, relationship profiles and their degrees of influence (Cavalcante et al., 2018).

In addition, the decentralization and agencification that has occurred in recent years, based on the guidance given to service users, an important component of the New Public Management movement, has made these managers assume roles and influence over relevant decisions, occupying spaces that were previously dedicated to high-level bureaucrats. Thus, these MLBs came to wield great potential influence in organizational, political and technical terms (Howlett, 2011; Jannuzzi, 2011; Lima \& Medeiros, 2012). Moreover, they entered the scope of bureaucratic activities such as efficient management and accountability (Osborne, 2010; Pollitt \& Bouckaert, 2011). 
The literature of public administration and public policy has tried to analyze the actions of MLBs using various analytical lenses. Some authors have focused on the activities performed by these bureaucrats, arguing, for example, that they manage gaps between rules and operations (Huising \& Silbey, 2011), a space in which they develop the intense work of translation, synthesis and learning. MLBs realize activities of different natures, circulating between the technical, the managerial and the political (Howlett, 2011; A. Oliveira, 2012; Pires, 2011).

The literature also notes intense work in terms of negotiation, articulation, and the establishment and regulation of relationships, due to the intermediary positions occupied by these actors (Bevir \& Rhodes, 2010; Johansson, 2012; Keiser, 2010). They have the power to exercise influence on their superiors as well as their subordinates (Kelly \& Gennard, 2007). Part of the national literature, for example, has sought to create a typology of MLBs based on their types of relationships and influences on policy (Cavalcante et al., 2018).

A portion of the literature has been dedicated to understanding the behavior of these bureaucrats. In studies involving MLBs in the federal government, Cavalcante and Lotta (2015) point out that one of the central dimensions used to explain their actions has been the use of individual and collective values in the bureaucracy's decision making. The studies of Abers (2015) have similar findings, presenting a perspective of actions based on activist values within the bureaucracy. Another relevant approach to understanding behavior is the Stewardship Theory, which seeks to place itself as a counterpart to the classic principal agent approach, which considers the behavior of bureaucrats as being a rational way to respond to the demands placed on them by the chain of command. To the Stewardship Theory, the implementor acts based on altruism without expecting something in return (Fontes, Ventura, \& Oliveira, 2008). Therefore, this behavior is explained based on the logic of cooperation and collectivity, team work and mutual collaboration (Davis, Schoorman, \& Donaldson, 1997). To this theory, the MLBs, besides encompassing the role of technical activities inherent in the function, also perform the roles of motivator, mobilizer and articulator of implemented public policy.

\subsection{Factors that influence mid-level bureaucrats in the public policy implementation process}

In order to better understand the analytical advances and limitations of the national literature concerning MLBs, we realized a SRL of empirical articles published between 2007 and 2017 based on the Capes and SPELL databases, to get a better understanding of the barriers observed during the implementation phase of public policies. We chose to analyze the national literature because the analysis of the actions of MLBs should always be contextualized (Pires et al., 2018), so that the conditions of their actions can be understood in light of their national context. At the same time, previous works have already reviewed the international literature (Pires et al., 2018), and these reviews have inspired the analyses that we have employed here.

For the literature analysis, we have used the peer reviewed journal criterion in the Capes database. In the SPELL database it was not possible to use this criterion because it is not available on the website. In the case of Capes, we used the term "implementação" contained in the title AND "políticas públicas" OR "política pública" as the keywords, totaling 88 articles. In the case of the SPELL database, we considered the term "implementação" contained in the title AND "políticas públicas" OR "política pública" as a keyword, totaling 10 articles. Relying on the same criteria but using the English terms 
"implementation" and "public policy", we obtained 80 articles in the Capes portal and 7 articles in the SPELL database.

Thus, 185 articles were obtained based on which the selection criteria were established by reading each abstract. The criteria adopted consisted in the exclusion of: a) articles repeated in the databases; b) articles which are not focused on this theme and do not involve Brazilian public policies; and c) theoretical articles or reviews which did not empirically analyze a policy.

Figure 1 illustrates this research.

\section{FIGURE 1 DESCRIPTION OF THE SYSTEMATIC REVIEW OF THE LITERATURE}
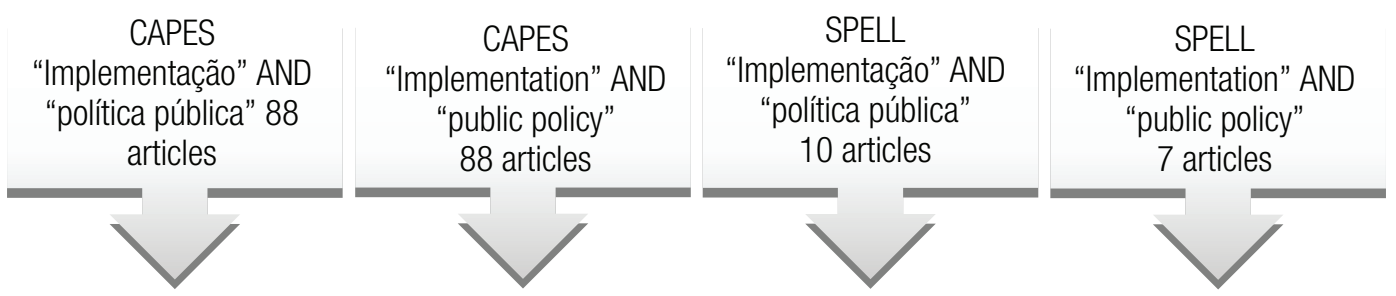

Repetitions: 10 articles

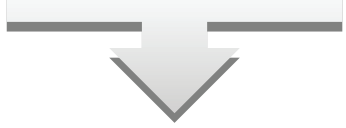

Different subject: 21 articles
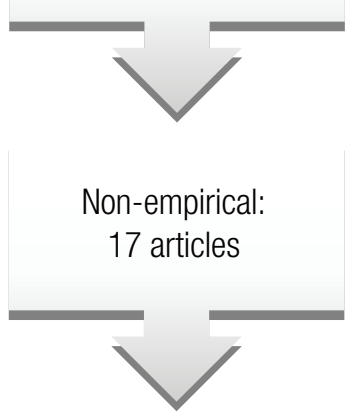

Analyzed: 40 articles
Repetitions: 6 articles
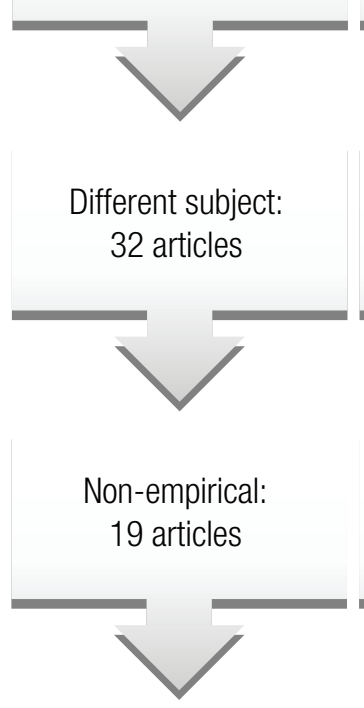
Analyzed: 23 articles

Repetitions: 2 articles

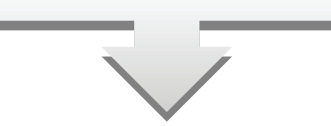

Different subject: 1 article

Different subject: 32 articles
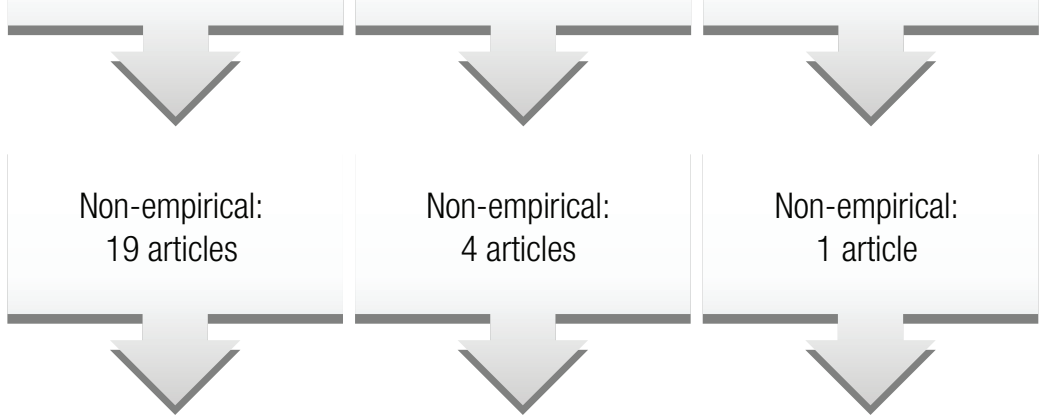

Non-empirical: 1 article

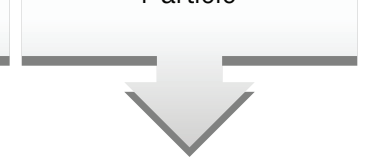

Analyzed: 4 articles

Analyzed: 2 articles

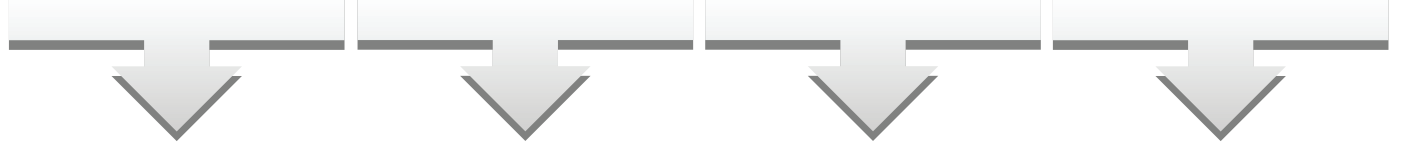

Total: 69 articles analyzed

Source: Elaborated by the authors. 
After the filtering, we extracted 69 empirical articles that analyze the public policy implementation process. An integral reading of these articles revealed the most often cited barriers which influence the public policy implementation process.

With the help of the categorization method proposed by Corley and Gioia (2004), these barriers were organized in terms of " $1^{\text {st }}$ Order Concepts" into approximately thirty concepts. The second phase was to summarize these concepts into "2nd Order Concepts", grouping them into synonymous terms. Finally, we consolidated them into "Aggregate Dimensions", which resulted into four categories considered in this article to be factors that influence public policy. These factors are organized as follows.

\subsubsection{Structural factors: physical, human and financial environment}

In planning a public policy, one of the primordial factors which formulating leaders should pay attention to is the appropriate structure to implement the policy. It includes the physical space itself, equipment and the necessary tools to implement the policy. The human structure, on the other hand, is the group of people necessary to meet the predicted demand for the policy, generally managed by the implementor. The financial structure has to do with the entire forecasted cost of maintaining the policy in operation.

In relation to structural factors, Menicucci and Marques (2016) present the results of a study which sought to analyze the degree of regionalization in the providing of health care. The authors sustain the position that the lack of an appropriate structure makes the implementation of the policy difficult on a regional level. Sharing the same barriers, Lobo-Recio et al. (2015) indicate that a lack of equipment and a limited number of collection stations for solid waste make policy implementation difficult. Meanwhile, Portes, Campos, Teixeira, Caetano, and Ribeiro (2014) highlight how the lack of professionals compromises the health care provided to beneficiaries of the policy, as does the inadequate structure of the units.

Bittencourt, Ferreira, and Brito (2017, p. 80) researched Reuni and show how a lack of structure harms the progress of this policy: "some results demonstrate that little attention was given to the issue of construction in the formulation of Reuni, given that many parts of the work suffered paralyzations, project revisions and cost overruns".

Or, in other words, the literature which analyzes the implementation of policies in Brazil has systematically presented structural barriers as a limiting element to implementation capacity which reflects on MLBs and their (in)capacity to implement the project.

\subsubsection{The human factor: policy implementors}

The figure of the policy implementor has gained more attention in some works that we examined in the SRL which point to the complexity and relevance of the actions of managers during implementation. Campanha, De Lorenzo, Fonseca, Oriani, and Paulillo (2017) demonstrate, in policy research oriented towards microentrepreneurs, that there is a dynamic imposed by the implementation of the law characterized by fragile interorganizational ties and relationships, which are based on maximizing individual interests to the detriment of the collective interests which should be pursued by public policies. If the implementor is not engaged in the policy and does not take the responsibility to provide a quality service, barriers can arise in the execution of the policy. 
Lima and Medeiros (2012), based on interviews with implementors, warn of another type of barrier: distrust and pessimism associated with the public policy which is being implemented. In addition, the fear of the policy being discontinued due to political issues and a lack of financial resources can lead to a lack of motivation and effort put into the work's execution. Klaster, Celeste, Wilderom, and Muntslag (2017) suggest that the implementation can be evaluated from the bottom-up, making it possible to see the role of implementors in its everyday execution. Casanova et al. (2017) show that the problems found in the front line are identified more rapidly in this manner than in an evaluation conducted from the top-down. In addition, implementors are considered to be the personification of the State in attending the needs of society and continually receiving feedback from policy users. Thus, the literature argues that the actions of bureaucrats are indispensable to understanding how policies function, given that they exercise a great influence on the implementation process.

\subsubsection{Public policy factor: regulation, planning and formulation}

Despite the fact that the barriers most often cited in the articles are identified where the policy occurs, there are problems that arise with its formulation which extend to the top of the pyramid, leading to consequences in the pyramid's base. This is the case with barriers that come from the public policy itself.

A study conducted in the State of São Paulo in the environmental area, points to policy regulation as a barrier to implementation: "the findings point to the need for a policy review, due to evidence of distortions caused by divergences between state and federal legislation, mainly in terms of the participating segments and the actors involved" (Malheiros, Prota, \& Peres, 2013, pp. 98-118).

These studies corroborate international theory, which points out the importance of a formulation which avoids conflicts and ambiguity, making it more feasible to execute the implementation (Matland, 1995).

\subsubsection{State factor: policy discontinuity, federation and autonomy}

Often the barriers and difficulties are not due to the policy or poor planning and formulation. Some barriers are caused at the top of the pyramid by the government and political will. Policy discontinuity caused by the electoral system or dysfunctions of the federal system in the Brazilian case, can lead to difficulties at the time of implementation. In addition, the lack of autonomy of executing bodies complicates the management and meeting of the beneficiaries' needs. These dysfunctions are also in accordance with international analyses, especially those which observe the implementation process top-down, such as the classic book by Pressman and Wildavsky (1973).

The lack of autonomy of executive bodies is another difficulty which is felt at the time of implementation. Ribeiro and Simionato (2016) demonstrate this problem in their research results involving public schools in Rio Grande do Sul. The authors found evidence that the autonomy of the schools was not respected in the implementation of the public policy. This factor is in line with the studies of Elazar (1994) and Arretche (2004), where they note the need to have incentives for cooperation in the solution of problems of collective action, and the challenge of reconciling the autonomy of the spheres of government with their interdependence and the decentralization of the 
executing bodies. Considering the complexity of this process, it has been necessary to develop studies that analyze the challenges for collective action in terms of implementation.

Based on the factors identified in the SRL, it was possible to relate them with the bureaucracy literature and determine how to extract the desired results from the empirical part of the article, which is illustrated in Box 2. It should be noted that most of the analyzed articles present more than one type of barrier at the same time. In this manner, here the objective has not been to portray all of the analyzed articles, but rather to research the most notable factors. Thus, as in the case of Exworthy, Berney, and Powell (2002), the factors identified in this bibliographic research can serve as the basis for future studies.

\section{BOX $2 \quad$ LIST OF FACTORS IN THE LITERATURE}

\begin{tabular}{|c|c|c|c|}
\hline Concepts & Description & How are they treated in the literature? & How are they extracted? \\
\hline $\begin{array}{l}\text { Structural } \\
\text { factors }\end{array}$ & $\begin{array}{l}\text { Physical, human and } \\
\text { financial environment. }\end{array}$ & $\begin{array}{l}\text { Structural factors are identified based on } \\
\text { the bottom-up model, which observes } \\
\text { policies from the perspective of the actors } \\
\text { who are closest to the implementation. }\end{array}$ & $\begin{array}{l}\text { Documental research and interviews } \\
\text { with MLBs to get their perceptions of } \\
\text { the structures, and whether they are } \\
\text { appropriate for policy implementation. }\end{array}$ \\
\hline Human factor & $\begin{array}{l}\text { Actors involved in the } \\
\text { policy implementation. }\end{array}$ & $\begin{array}{l}\text { Analysis of the behavior, values and } \\
\text { motivation of MLBs (Cavalcante \& Lotta, } \\
\text { 2015). }\end{array}$ & $\begin{array}{l}\text { Identifying in interviews with } \\
\text { bureaucrats their perceptions of their } \\
\text { role in policy implementation. }\end{array}$ \\
\hline $\begin{array}{l}\text { Public policy } \\
\text { factor }\end{array}$ & $\begin{array}{l}\text { Regulation, planning } \\
\text { and formulation }\end{array}$ & $\begin{array}{l}\text { Based on looking at the multiple influences } \\
\text { and interdependencies between the policy } \\
\text { phases, and mainly the dynamism and } \\
\text { the relationship between formulation and } \\
\text { implementation (Gontijo, 2010; Lotta, } \\
\text { 2019; Matland, 1995; Secchi, 2013). }\end{array}$ & $\begin{array}{l}\text { Based on bureaucratic considerations, } \\
\text { it may be perceived whether the policy } \\
\text { was well formulated and planned, } \\
\text { which spaces were left for adaptation } \\
\text { and interpretation in the field; and } \\
\text { whether their regulation meets the } \\
\text { stipulated objectives. Research based } \\
\text { on interviews and documental analysis } \\
\text { of regulations and formulations. }\end{array}$ \\
\hline State factor & $\begin{array}{l}\text { Policy discontinuity, } \\
\text { federation dynamic } \\
\text { and organizational } \\
\text { autonomy. }\end{array}$ & $\begin{array}{l}\text { Incentives for cooperation in the solution of } \\
\text { problems of collective action; reconciling } \\
\text { the autonomy of spheres of government } \\
\text { with the interdependencies between them } \\
\text { (Arretche, 2004; Elazar, 1994). }\end{array}$ & $\begin{array}{l}\text { How a bureaucrat perceives the } \\
\text { actions of politicians and governments } \\
\text { and the functioning of the State } \\
\text { and its various layers during policy } \\
\text { implementation. }\end{array}$ \\
\hline
\end{tabular}

Source: Elaborated by the authors.

The empirical material presented below was analyzed based on the dimensions found in the literature. 


\section{RESULTS AND DISCUSSIONS}

\subsection{Description of Reuni in UFG}

The adhesion of UFG to the Reuni was discussed in June and July 2007 when a commission was created by the University Board (Consuni) to discuss and present a Plan for the Restructuring and Expansion of UFG. This commission was constituted by members who volunteered to participate and others who were invited due to their technical competence. Nine members formed the commission (among department heads, academic unit directors, and paid managers). Adhesion was a democratic act and one of the first decisions of the commission was to forward a solicitation to academic units to discuss this subject and respond with their intentions in terms of expansion. Of the 24 academic units in UFG, 23 adhered to the program.

The Reuni was regulated by the Ministry of Education (MEC), which through Decree No. 6,096 (2007) established targets to be met by Higher Education institutions by the end of the implementation period (2007-2012). The document presents the general guidelines of Reuni, the indicator calculation parameters and the global targets. In this manner, UFG managed to open 2,737 new spaces for the college entrance exams (today determined by the National High School Exam [Enem]), with approximately 650,000 square feet of constructed area, 291 new technical administration professionals and 476 new professors. The sum spent by the end of 2013 (the end of the construction) on the university's expansion was approximately R $\$ 80$ million. This expansion was directly linked to the quantity of new spaces available.

Despite the fact that UFG expanded its number of available positions in a satisfactory manner, the global targets stipulated by the MEC were not achieved. The average conclusion rate for courses established by the MEC was $90 \%$ and UFG achieved $64.41 \%$; which has to do with the ratio of 18 students per professor stipulated by the MEC, while UFG achieved 14.71. In terms of the other requirements in Article 2 of Decree no. 6,096 (2007), UFG managed to fulfill most in a satisfactory manner, giving priority to the expansion of public policies for student assistance which succeeded in making the openings at UFG more democratic and changing the profile of admitted students from "elite" to "egalitarian".

\subsection{Perceptions of mid-level bureaucrats}

Field analyses demonstrate the perception that MLBs in implementing the Reuni policy at UFG performed, in addition to technical roles, that of motivators and mobilizers of policy through their teams. This finding is in accordance with studies by Jeannot (2005) and contribute to theory in respect to the roles performed by MLBs in policy planning. In addition, the MLBs point to better planning and demand forecasts to expand Higher Learning as ways to ameliorate the desistance of students at UFG. This perception disagrees with the results presented by T. S. Souza (2017) which found that this desistance at UFG occurred mainly due to socioeconomic factors.

Unlike what traditionally occurs with public policies in Brazil, which is reinforced by studies such as Vitkauskas (2013) and Lima and Medeiros (2012), the government fulfilled its commitment to the universities by making the planned budget available within the timeframe stipulated for the 
implementation of Reuni and most of the MLBs recognize this positive point. The financial issue thus does not appear to have been a barrier to the implementation of this policy. Another point observed was that the personal satisfaction derived from implementing an affirmative public policy and the confidence in the team motivated the MLBs involved in executing the program. They also emphasized the importance of the role played by social actors in this policy. This confirms the studies of Davis et al. (1997), who indicated the altruistic behavior of bureaucrats by terming them stewards.

Another observed perception was that the high-level bureaucracy of the university used democratic management, giving MLBs a more visible role. In other words, the MLBs felt more responsible and dedicated to implementing the policy. A large portion of the interviewees also informed us that, in addition to fulfilling the technical characteristics inherent in their positions, they acted as motivators and mobilizers in the Reuni policy. This finding helps advance theory in terms of understanding how MLBs see themselves in the roles that they perform.

Meanwhile, in terms of the public policy factor, some Reuni targets were considered unattainable by the MLBs, which generated a lack of motivation and disinterest on the part of some of the teams. This perception is in accordance with the studies of Theodolou and Cahn (1995), C. Souza (2006) and Garcia (2014) about the formulation of public policy targets. The short timeframe stipulated by the Reuni implementation harmed the policy maturation stage and inhibited a better use of this time which involved great and significant changes for UFG. The regulation of the policy was considered cumbersome by the interviewees, which made customization difficult in light of the obstacles observed by the actors involved at the time of implementation. Jannuzzi (2011) shows these types of difficulties in the implementation of public policies that do not attain a certain degree of maturity to get the most out of them. These perceptions reaffirm what the literature says about the relationship between the formulation and implementation of policies.

In terms of the relationship of the State with MLBs, the distrust of the academic community in terms of seeing the policy through until the end was considered one of the most controversial results. In the university's act of adhering to Reuni, some groups displayed their opposition, some for politicalparty issues and others because they did not believe in the continuity of the policy. This fact made the work of the MLBs and their teams difficult. Troubles in relation to autonomy were also found in the study of Brandt and Brandt (2016) - in terms of the agency problem in the implementation of public policies - and in the study of Ribeiro and Simionato (2016) - involving the autonomy of municipal schools. UFG, meanwhile, had the autonomy to manage the implementation of Reuni, which facilitated the implementation process. This evidence is different from that already pointed out by the literature in respect to the lack of administrative autonomy in educational units.

Another fact mentioned by the interviewees was the use of academic units in the mediation between their role in managing people, the political role inherent in a trusted position, and their operational role. The interviews indicate that this mediation was not balanced, which generated discomfort in the teams. This finding is similar to those of studies by A. Oliveira (2012) and Lima and D'Ascenzi (2017) and endorses the characteristics proposed by Cavalcante and Lotta (2015) about the multiple functions of MLBs. The numerical evaluation of the MEC in relation to Reuni was considered incomplete by the interviewees, because it did not manage to capture the problems generated in the base of the pyramid at the moment of implementation. This evidence corroborates the analysis of A. Oliveira (2012). 
Box 3 summarizes the main empirical findings in light of the literature.

\section{BOX 3 SUMMARY OF THE MAIN PERCEPTIONS}

\begin{tabular}{|c|c|c|}
\hline Factors & Perceptions observed in the field & Basis for this in the literature \\
\hline $\begin{array}{l}\text { Structural } \\
\text { factors }\end{array}$ & $\begin{array}{l}\text { The personal perceptions, for the most part, are not in } \\
\text { accordance with what appears in the literature. }\end{array}$ & $\begin{array}{l}\text { 1. Jeannot (2005) } \\
\text { 2. T. S. Souza (2017) } \\
\text { 3. Vitkauskas (2013) }\end{array}$ \\
\hline Human factor & $\begin{array}{l}\text { The observed perceptions are for the most part in } \\
\text { accordance with what has been identified in the } \\
\text { literature. }\end{array}$ & 1. Davis et al. (1997) \\
\hline $\begin{array}{l}\text { Public policy } \\
\text { factor }\end{array}$ & $\begin{array}{l}\text { The perceptions of the MLBs are in accordance with } \\
\text { what has been addressed in the literature. }\end{array}$ & $\begin{array}{l}\text { 1. C. Souza (2006) } \\
\text { 2. Theodolou and Cahn (1995) } \\
\text { 3. Garcia (2014) } \\
\text { 4. Jannuzzi (2011) }\end{array}$ \\
\hline State factor & $\begin{array}{l}\text { This factor is also found in a large part of the studies } \\
\text { in the literature. }\end{array}$ & $\begin{array}{l}\text { 1. Brandt and Brandt (2016) } \\
\text { 2. Ribeiro and Simionato (2016) } \\
\text { 3. Lima and D'Ascenzi (2017) } \\
\text { 4. A. Oliveira (2012) } \\
\text { 5. Cavalcante and Lotta (2015) }\end{array}$ \\
\hline
\end{tabular}

Source: Elaborated by the authors.

At the end of the interviews a single question was asked, referring to the overall objective of this study:

- What is your perception in terms of the implementation of Reuni within the context of UFG?

All of the respondents recognized the importance of Reuni in UFG in structural, personnel and learning terms, as well as in terms of affirmative action and assistance. Not all, however, considered it to be a "good" implementation. Among the 14 people interviewed, 6 believe that their roles as implementors of the policy could have been better if there were adequate technical and emotional preparation. In addition, others commented that the quantitative measurement made by MEC was wanting in terms of managers who had no managerial training.

AU 4 said:

We were not trained for this, but I took it as a personal challenge to play a part in the largest expansion policy conducted in the history of Higher Education in this country.

Many interviewees (8) cited, moreover, that if there was a new Reuni, they would act differently, such as "taking greater advantage of this opportunity of funding to expand more" or "studying and planning so that this expansion would be of greater quality", or even correct individual problems, such 
as "the number of technical administrators was not sufficient to provide support for the expansion". They also perceived that due to the autonomy given to the directors of academic units, they worked in a different manner in each unit. This was also caused by the breadth of the norms which governed the program, which conceded space for interpretation and adaptation (Matland, 1995). The directors of the academic units also considered the most difficult tasks as managers to be influencing people and motivating them to follow the planning, because

[...] the technical aspect is supported by software and people who understand the subject, which requires previous preparation, however the emotional preparation and how to deal with people demanded a lot from us during the entire process, and this we were not prepared for (AU 5).

\section{FINAL CONSIDERATIONS}

In analyzing the perceptions of MLBs in the implementation of Reuni at UFG (from 2007 to 2012), this article seeks to contribute to the field by diminishing the gaps in studies about MLBs in the function of public policy implementors. To sum up, the implementation of Reuni at UFG can be considered a great opportunity that the university had to expand in terms of structure, personnel and learning, as well as realizing affirmative action and assistance. The authors perceive that the organizational structures which were thought out in a democratic manner provided greater space so that MLBs could perform their roles satisfactorily. The breadth of the norms also gave them decision-making autonomy, increasing the space available for interpretation and adaptation - which strengthened the role of these mid-level actors. Based on the perceptions of the interviewees, it was observed that the formulation of public policy, when realized in a cumbersome manner, creates a lack of motivation on the part of the team, making the managerial work of MLBs more difficult.

The Reuni policy counted on an entire budget, which was highlighted as a positive point in its implementation, and this was not the case with other policies analyzed in the literature. And finally, the perception of these bureaucrats as social actors in a policy to expand Higher Education was that of great satisfaction based on the role they performed.

In terms of this study's limitations, we may note that:

- This study is dedicated to MLBs in UFG, since it was not viable to analyze MLBs acting in the implementation of Reuni in other institutions of Higher Learning;

- There was difficulty in identifying who were the MLB policy implementors in the institution; and, finally,

- It was necessary to deal with complexity in analyzing the categorized empirical material, given that the factors that influence the implementation of public policies are multifaceted and interlinked.

We would suggest the realization of new studies, such as, for example, the implementation of other public education policies, using the methodology adopted here. We would also recommend that future studies incorporate other findings in the international literature about what conditions the actions of MLBs. Comparative studies would also be promising from the point of view of the role played by MLBs in institutions of Higher Learning which have implemented Reuni, with widely varying results. 


\section{REFERENCES}

Abers, R. N. (2015). Ativismo na burocracia? O médio escalão do Programa Bolsa Verde. In P. Cavalcante, \& G. Lotta (Eds.), Burocracia de médio escalão: perfil, trajetória e atuação (pp. 143-175). Brasília, DF: Escola Nacional de Administração Pública.

Andrade, G. (2018). Burocracia de médio escalão: uma análise da atuação no nível municipal a partir da abordagem dos arranjos institucionais (Doctoral Dissertation). Universidade Federal do ABC, São Bernardo do Campo, SP.

Arretche, M. (2004). Federalismo e políticas sociais no brasil: problemas de coordenação e autonomia. São Paulo em Perspectiva, 18(2), 17-26.

Bardin, L. (2004). Análise de conteúdo (3a ed.). Lisboa, Portugal: Ed. 70.

Bevir, M., \& Rhodes, R. A. W. (2010). The State as cultural practice. Oxford, England: Oxford University Press.

Bittencourt, M. F. N., Ferreira, P. A., \& Brito, M. J. (2017). Avaliação do processo de implementação de obras públicas em universidades federais: um estudo do programa Reuni. Revista Gestão Universitária na América Latina, 10(1), 79-102.

Brandt, L. M. \& Brandt, L. J. (2016). Delinquência Juvenil: Causas e Consequências. Ix Mostra Internacional De Trabalhos Científicos.

Brodkin, E. Z. (2012). Reflections on street-level bureaucracy: past, present, and future. Public Administration Review, 72(6), 940-949.

Cabral, A., Romero, C., Penha E., Alves, R., \& Parente, T. (2014). Reestruturação e expansão do Ensino Superior público: o programa Reuni na Universidade Federal do Ceará sob a visão dos alunos. Revista do Serviço Público, 62(3), 297-319.

Campanha, L. J., De Lorenzo, H. C., Fonseca, S. A., \& Oriani e Paulillo, L. F. (2017). Formulação e implementação, convergências e desvios: facetas da política pública do micro empreendedor individual (MEI) no plano local. Gestão \& Produção, 24(3), 582-594.

Casanova, L., Oliveira, A., Cruz, D., Marques, M., Alves, G. L., Reis, G., \& Cardoso, G. (2017). A implementação de redes de atenção e os desafios da governança regional em saúde na Amazônia Legal: uma análise do Projeto QualiSUS-Rede. Ciência \& Saúde Coletiva, 22(4), 1209-1224.
Casari, P. (2014). Avaliação da expansão recente da Universidade Federal de Goiás segundo a ótica do mercado de trabalho. Gestão \& Regionalidade, 30(90), 4-17.

Cavalcante, P., \& Lotta, G. (Eds.) (2015). Burocracia de médio escalão: perfil, trajetória e atuação. Brasília, DF: Escola Nacional de Administração Pública.

Cavalcante, P., Lotta, G., \& Yamada, E. (2018). O desempenho dos burocratas de médio escalão: determinantes do relacionamento e das suas atividades. Cadernos EBAPE.BR, 16(1), 14-34.

Codato, A., \& Franz, P. (2018). Ministros-técnicos e ministros-políticos nos governos do PSDB e do PT. Revista de Administração Pública, 52(5), 776-796.

Corley, K. G., \& Gioia, D. A. (2004). Identity ambiguity and change in the wake of a corporate spin-off. Administrative Science Quarterly, 49, 173-208.

Creswell, J. W. (2007). Projeto de pesquisa: métodos qualitativo, quantitativo e misto. Porto Alegre, RS: Bookman.

Davis, J. H., Schoorman, F. D., \& Donaldson, L. (1997). Toward a stewardship theory of management. Academy of Management Review, 22(1), 20-47.

Decreto n. 6.096, de 24 de abril de 2007. (2007). Institui o Programa de Apoio a Planos de Reestruturação e Expansão das Universidades Federais - Reuni. Brasília, DF.

Elazar, D. J. (1994). Federalismo. Archè, 3(7), 7-30.

Exworthy, M., Berney, L., \& Powell, M. (2002). How great expectations in Westminster may be dashed locally: the local implementation of national policy on health inequalities. Policy \& Politics, 30(1), 79-96.

Fontes, J. R., Filho, Ventura, E. C. F., \& Oliveira, M. J. (2008). Governança e participação no contexto das cooperativas de crédito. Revista de Administração FACES Journal, 7(3), 48-63.

Garcia, A. (2014). A implementação de políticas públicas de ambiente - o caso da qualidade da água para consumo humano. Análise Social, 49(211), 310-343.

Gontijo, J. G. L. (2010). Gestão pública, desarticulação e concertação: um estudo empírico sobre coordenação e cooperação no âmbito das políticas para juventude em Belo Horizonte. Administração Pública e Gestão Social, 2(4), 39-64. 
Howlett, M. (2011). Public managers as the missing variable in policy studies: an empirical investigation using Canadian data. Review of Policy Research, 28(3), 247-263.

Huising, R., \& Silbey, S. S. (2011). Governing the gap: forging safe science through relational regulation. Regulation \& Governance, 5(1), 14-42.

Jannuzzi, P. M. (2011). Avaliação de programas sociais no Brasil: repensando práticas e metodologias das pesquisas avaliativas. Planejamento e Políticas Públicas, 36, 251-275.

Jeannot, G. (2005). Lesmétiers flous: travailetaction publique. Toulouse, France: Octarès.

Johansson, V. (2012). Negotiating bureaucrats. Public Administration, 90(4), 1032-1046.

Keiser, L. R. (2010). Understanding street-level bureaucrats' decision making: determining eligibility in the social security disability program. Public Administration Review, 70(2), 247-257.

Kelly, J., \& Gennard, J. (2007). Business strategic decision making: the role and influence of directors. Human Resource Management Journal, 17(2), 99117.

Klaster, C., Celeste, P., Wilderom, M., \& Muntslag, D. R. (2017). Balancing relations and results in regional networks of public-policy implementation. Journal of Public Administration Research and Theory, 27(4), 676-691.

Lima, L., \& D’Ascenzi, L. (2017). O papel da burocracia de nível de rua na implementação e (re) formulação da Política Nacional de Humanização dos Serviços de Saúde de Porto Alegre (RS). Revista de Administração Pública, 51(1), 46-63.

Lima, M., \& Medeiros, J. (2012). Empreendedores de políticas públicas na implementação de programas governamentais. Revista de Administração Pública, 46(5), 1251-1270.

Lipsky, M. (1980). Street-level bureaucracy: dilemmas of the individual in public service. New York, NY: Russel Serge Foundation.

Lobo-Recio, M. A., Madruga, K. C. R., Bilésimo, T., Rossi, C. R., Bernardy, A. R., \& Mussi, R. (2015). Educacão ambiental e implementação de políticas públicas: a experiência em Araranguá/SC. Revista Políticas Públicas \& Cidades, 3(2), 100-119.
Lotta, G. (2019). Teorias e análises sobre implementação de políticas públicas no Brasil. Brasília, DF: Escola Nacional de Administração Pública.

Loureiro, M., \& Abrucio, F. (2018). Burocracia e ordem democrática: desafios contemporâneos e experiência brasileira. In R. Pires, G. Lotta, \& V. Oliveira (Orgs.), Burocracia e políticas públicas no Brasil (pp. 23-58). Brasília, DF: Instituto de Pesquisa Econômica Aplicada.

Malheiros, T. F., Prota, M. G., \& Perez R. M. A. (2013). Participação comunitária e implementação dos instrumentos de gestão da água em bacias hidrográficas. Revista Ambiente \& Água, 8(1), 98118.

Matland, R. (1995). Synthesizing the implementation literature: the ambiguity-conflict model of policy implementation. Journal of Public Administration Research and Theory, 5(2), 145-174.

Menicucci, T., \& Marques, A. M. F. (2016). Cooperação e coordenação na implementação de políticas públicas: o caso da saúde. Dados, 59(3), 823-865.

Ministério da Educação. (2017). Análise sobre a expansão das universidades federais de 2003 a 2012. Brasília, DF: MEC.

Oliveira, A. (2012). Burocratas da linha de frente: executores e fazedores das políticas públicas. Revista de Administração Pública, 46(6), 1551-1573.

Oliveira, A. J., Almeida, L. B., Carneiro, T. C. J., \& Scarpin, J. E. (2014). Programa Reuni nas instituições de Ensino Superior federal [IFES] brasileiras: um estudo da eficiência operacional por meio da análise envoltória de dados [DEA] no período de 2006 a 2012. RACE: Revista de Administração, Contabilidade e Economia, 13(3), 1179-1210.

Oliveira, V. E., \& Abrucio, F. L. (2011). Entre a política e a burocracia: a importância dos burocratas de nível médio para a produção de políticas públicas em saúde e educação. In Anais do 35o Encontro Anual da Anposs. Caxambu, MG.

Oliveira, V. E., Lotta, G., \& Nunes, M. (2019). Desafios da implementação de uma política intersetorial e federativa: as burocracias de médio escalão do Programa Bolsa Família. Revista do Serviço Público, 70, 458-480. 
Osborne, S. (Ed.). (2010). The new public governance: emerging perspectives on the theory and practice of public governance. London, England: Routledge.

Pires, R. (Org.). (2011). Efetividade das instituições participativas no Brasil: estratégias de avaliação. Brasília, DF: Instituto de Pesquisa Econômica Aplicada.

Pires, R., Lotta, G., \& Oliveira, V. (Orgs.). (2018). Burocracia e políticas públicas no Brasil. Brasília, DF: Instituto de Pesquisa Econômica Aplicada.

Pollitt, C., \& Bouckaert, G. (2011). Public management reform: a comparative analysis - new public management, governance, and the neo-Weberian State. Oxford, England: Oxford University Press.

Portes, L. H., Campos, E. M. S., Teixeira, M. T. B., Caetano, R., \& Ribeiro, L. C. (2014). Ações voltadas para o tabagismo: análise de sua implementação na atenção primária à saúde. Ciência \& Saúde Coletiva, 19(2), 439-448.

Pressman, J., \& Wildavsky, A. (1973). Implementation. Berkeley, CA: University of California Press.

Ribeiro, J. A. R., \& Simionato, M. F. (2016). O caso do Ensino Médio politécnico e a avaliação de sua implementação nas escolas públicas gaúchas. Arquivos
Analíticos de Políticas Educativas, 24(115-116), 1-24.

Secchi, L. (2013). Políticas públicas: conceitos, esquemas de análise, casos práticos (2a ed.). São Paulo, SP: Cengage Learning.

Siqueira, J. S. (2015). Eficiência das universidades públicas federais brasileiras: um estudo com foco no projeto Reuni (Master Thesis). Universidade Federal da Paraíba, João Pessoa, PB.

Souza, C. (2006). Políticas públicas: uma revisão da literatura. Sociologias, 8(16), 20-45.

Souza, T. S. (2017). Estudo sobre a evasão em cursos de graduação presenciais na Universidade Federal de Goiás - UFG (Master Thesis). Universidade Federal de Goiás, Catalão, GO.

Theodoulou, S. \& Cahn, M. (1995). Public Policy: The Essential Readings. New Jersey: California State University. 1995.

Vitkauskas, K. (2013). Activity of preventive subdivisions of public police in implementation of prevention of juvenile delinquency. Public Policy and Administration, 12(1), 22-35.

Yin, R. (2005). Estudo de caso: planejamento e métodos. Porto Alegre, RS: Bookman.

\section{Valéria de Oliveira Lemos Novato}

https://orcid.org/0000-0002-9556-8736

Master's in Administration from the Faculty of Administration, Accounting and Economic Sciences at the Federal University of Goiás (FACE/UFG). E-mail: valnovato.ufg@gmail.com

\section{Estela Najberg}

https://orcid.org/0000-0002-2852-4442

$\mathrm{PhD}$ in Administration; Associate Professor in the Faculty of Administration, Accounting and Economic Sciences at the Federal University of Goiás (FACE/UFG). E-mail: estelanajberg@gmail.com

\section{Gabriela Spanghero Lotta}

https://orcid.org/0000-0003-2801-1628

$\mathrm{PhD}$ in Political Science; Professor of Public Administration and Government in the São Paulo School of Business Administration of the Getulio Vargas Foundation (FGV EAESP). E-mail: gabriela.lotta@fgv.br 